\title{
Rekomendasi Penentuan Harga Jual Untuk Warangka Keris Menggunakan Logika Fuzzy Mamdani
}

\author{
Rama Joko Pamungkas ${ }^{1}$, Hanny Haryanto ${ }^{2}$, Setia Astuti ${ }^{3}$, Erna Zuni Astuti ${ }^{4}$, Yuniarsi Rahayu $^{5}$ \\ Program Studi Teknik Informatika, Universitas Dian Nuswantoro \\ Jalan Imam Bonjol 207 Semarang, Indonesia \\ 1111201207323@mhs.dinus.ac.id \\ 2hanny.haryanto@dsn.dinus.ac.id (Corresponding author) \\ 1setia.astuti@mhs.dinus.ac.id \\ 1erna.zuni.astuti@mhs.dinus.ac.id \\ 1yuniarsi.rahayu@mhs.dinus.ac.id
}

\begin{abstract}
Abstrak
Indonesia adalah negara yang kaya akan sumber daya alam dan keanekaragam budaya dan bahasa banyak diantaranya yang telah diakui UNESCO (United Nation Educational, Scientific and Cultural Organization). Salah satunya adalah keris yang telah ditetapkan sebagai Warisan Kemanusiaan Budaya Lisan dan Nonbendawi (Masterpieces of the oral and Intangible Heritage of humanity) sejak 25 November 2015. Karena itulah munculnya peluang usaha bagi masyarakat Indonesia untuk melakukan bisnis pusaka nusantara ini terutama dalam bidang warangka keris. Kendala mereka terdapat pada penetapan harga warangka keris. Banyak warangka keris yang memiliki harga yang tidak sesuai kualitasnya dan tidak sesuai dengan harga pasar. Oleh karena itu pembisnis baru banyak yang kalah bersaing dari orang yang telah mendirikan bisnis warangka keris sejak puluhan tahun. Karena itulah dibutuhkan sebuah sistem yang dapat menentukan harga jual warangka keris dengan menggunakan metode Logika Fuzzy Mamdani. Dengan adanya sistem ini dapat memberikan harga warangka keris sesuai dengan harga pasar. Hasil dari penelitian ini adalah menentukan harga jual warangka keris dengan selisih error MAE (Mean Absolute Error) sebesar Rp. 43.252,05.
\end{abstract}

Keywords: Fuzzy Mamdani, Harga, Penjualan, Warangka Keris

\section{Pendahuluan}

Salah satu peninggalan budaya bangsa Indonesia adalah keris [1]. Keris merupakan senjata tikam golongan belati (berujung runcing dan tajam pada kedua sisinya). Bentuknya yang khas dan mudah dibedakan dari senjata tajam lainnya karena tidak simetris dari pangkal yang melebar [1]. Pusaka keris Indonesia telah mendapat penghargaan dari UNESCO (United Nations Educational, Scientific and Cultural Organization) dan ditetapkan sebagai Warisan Kemanusiaan untuk Budaya Lisan dan Nonbendawi (Masterpieces of the Oral and Intangible Heritage of Humanity) sejak 25 November 2015 [2]. Ini menyebabkan munculnya peluang usaha bagi masyarakat Indonesia untuk melakukan bisnis keris, terutama di bidang warangka keris. Banyak orang yang ingin memulai bisnis ini tetapi terkendala pada penetapan harga warangka keris. Banyak warangka keris yang memiliki harga yang tidak sesuai kualitasnya dan tidak sesuai dengan harga pasar [3]. Banyak patokan yang digunakan pengrajin untuk menentukan harga jual sebuah keris, Harga jual batik dapat ditentukan dari jenis kayu, jenis pelet, Handle, jenis logam yang digunakan untuk membuat pamor keris bahkan nilai sejarah dari keris tersebut seperti pembuat keris dan keris tersebut pernah dipakai seorang tokoh tertentu [4].

Tujuan dari penelitian ini adalah menerapkan logika Fuzzy Mamdani untuk membantu menentukan harga jual warangka keris. Konsep penerapan sistem fuzzy diperkenalkan oleh Prof. Lotfi Astor Zadeh pada tahun 1962. Pengertian dari logika fuzzy itu sendiri adalah suatu sistem yang digunakan untuk memecahkan suatu masalah yang mempunyai ketidakpastian dan mempunyai banyak jawaban untuk mengimplementasikan ke dalam sistem kontrol baik yang 
sederhana, sistem besar, multi-channel, system embedded, dan jaringan. Metode logika fuzzy juga dapat dikombinasikan ke dalam perangkat lunak (software), perangkat keras (hardware), dan dapat juga dikombinasikan kedua-duanya [2]. Metode yang digunakan dalam menerapkan penelitian ini adalah metode mamdani, metode ini lebih dikenal dengan metode Max-Min. Metode ini diperkenalkan oleh Ebrahin Mamdani pada tahun 1975. Dan untuk memperoleh output dari metode ini diperlukan 4 tahapan yaitu: menentukan himpunan fuzzy, amplikasi fungsi implikasi (aturan), komposisi aturan, dan penegasan.

Fuzzy telah banyak digunakan untuk menyelesaikan berbagai permasalahan. Diantaranya adalah [5] dalam jurnalnya yang membuat sistem pendukung keputusan beasiswa diklat dengan fuzzy MADM. Penelitian ini dilakukan dengan cara mencari nilai bobot, kemudian dilakukan proses perengkingan untuk menentukan alternatif yang diberikan. Dengan adanya penelitian ini diharapkan dapat mempercepat proses perangkingan serta mengurangi kesalahan dalam menentukan beasiswa dan membantu tim penyeleksi dalam menentukan penerimaan beasiswa. Kemudian [6] membahas tentang sistem yang digunakan untuk mendukung dalam mengambil keputusan menentukan parameter kelulusan perguruan tinggi. Parameter lulusan dapat dilihat dari strategis dan sudut pandang eksekutif dalam periode tertentu. Dalam institusi pendidikan, parameter lulusan menjadikan suatu faktor yang memberikan pengaruh besar terhadap kepercayaan masyarakat. Penelitian ini menggunakan konsep ELT, OLAP yang digunakan untuk menganalisis dan menentukan indeks KPI, setelah itu indeks KPI tersebut di analisis dengan menggunakan metode fuzzy model Tsukamoto untuk mengevaluasi lulusan. Penelitian oleh [7] membahas tentang produk yang paling banyak terjual di sebuah minimarket. Jumlah mie instan yang terjual ke konsumen setiap harinya tidak secara konstan, sehingga sering terjadinya ketidak sesuaian minimarket dalam membeli mie dari supplier, yang mengakibatkan sisa stok mie instan bisa terjadi kekurangan atau kelebihan. Dari sinilah penulis menemukan ide untuk memprediksi produk mie instan dengan metode takagi sugeno. Dengan adanya penelitian ini metode fuzzy takagi-sugeno dapat memprediksi pembelian mie instan dari sebuah minimarket, sehingga meminimalisir terjadinya kelebihan dan kekurangan mie instan. Penelitian ini terdapat selisih error MAPE sebesar $35,55 \%$. Selanjutnya [8] membahas tentang Sistem Pendukung Keputusan untuk membantu konsumen dalam memilih smartphone. Penelitian ini membandingkan antara perhitungan secara manual dengan perhitungan secara system dan hasilnya tidak ada perbedaan secara manual maupun sistem. Penelitian yang juga menggunakan fuzzy adalah [1] untuk menentukan harga jual batik dengan fuzzy mamdani. Dari penelitian-penelitian tersebut didapatkan bahwa fuzzy tepat menangani suatu permasalahan yang memerlukan intuisi, seperti pada penentuan harga warangka keris.

Penelitian ini akan menerapkan Fuzzy Mamdani untuk membantu penentuan harga warangka keris. Ruang lingkup dan batasan dalam maksimal enam kriteria saja yaitu proses kualitas kayu, pelet, handle, stok, permintaan yang digunakan untuk menentukan harga jual atau keluaran.

\section{Metode Penelitian}

Dalam penyusunan penerapan logika fuzzy mamdani untuk menentukan harga jual warangka keris dilakukan beberapa langkah untuk mendapatkan data valid. Hal ini dilakukan untuk mendapatkan harga warangka keris yang diharapkan.

\subsection{Menentukan himpunan fuzzy}

Tahap pertama yang dilakukan adalah penyusunan fungsi keanggotaan dengan rumus untuk kurva segitiga adalah sebagai berikut.

$$
\text { Triangular }(x, a, b, c)=\left\{\begin{array}{c}
0, x \leq a, x \geq c \\
\frac{x-a}{b-a}, a<x<b \\
\frac{c-x}{c-b}, b<x<c \\
1, x=b
\end{array}\right.
$$


Sedangkan untuk kurva trapezium dapat dirumuskan sebagai berikut.

$\operatorname{Trapezium}(x, a, b, c, d)=\left\{\begin{array}{l}0, x \leq a, x \geq d \\ \frac{x-a}{b-a}, a<x<b \\ \frac{d-x}{d-c}, c<x<d \\ 1, b \leq x \leq c\end{array}\right.$

\section{a. Variabel kualitas kayu}

Variabel kualitas disini dipakai untuk menganalisa handle yang digunakan pada warangka keris dan jumlah pelet yang melekat pada kayu tersebut apakah mempunyai kualitas yang tinggi atau mempunyai kualitas yang rendah. Tabel 1 menunjukkan tingkat fuzzy untuk kualitas kayu. Derajat keanggotaan untuk kualitas kayu ditunjukkan pada Gambar 1.

Tabel 1. Kualitas Kayu

\begin{tabular}{ccc}
\hline No & Kualitas Kayu & Tingkat Fuzzy \\
\hline 1 & $1-40$ & Rendah \\
\hline 2 & $20-80$ & Standar \\
\hline 3 & $60-100$ & Tinggi \\
\hline & & \\
\hline
\end{tabular}

Gambar 1. Himpunan Kualitas Kayu

b. Variabel Himpunan Handle

Variabel Handle digunakan untuk menentukan harga handle. Kebanyakan berbahan dasar kayu yang keras, berserat bagus dan gampang dibentuk. biasanya ladrang-gayaman sering diganti dengan gading. Tabel 2 menunjukkan tingkat fuzzy untuk handle. Derajat untuk himpunan handle ditunjukkan pada Gambar 2.

Tabel 2. Handle

\begin{tabular}{ccc}
\hline No & Handle & Tingkat Fuzzy \\
\hline 1 & $100.000-2.000 .000$ & Kayu \\
\hline 2 & $300.000-3.000 .000$ & Gading \\
\hline
\end{tabular}

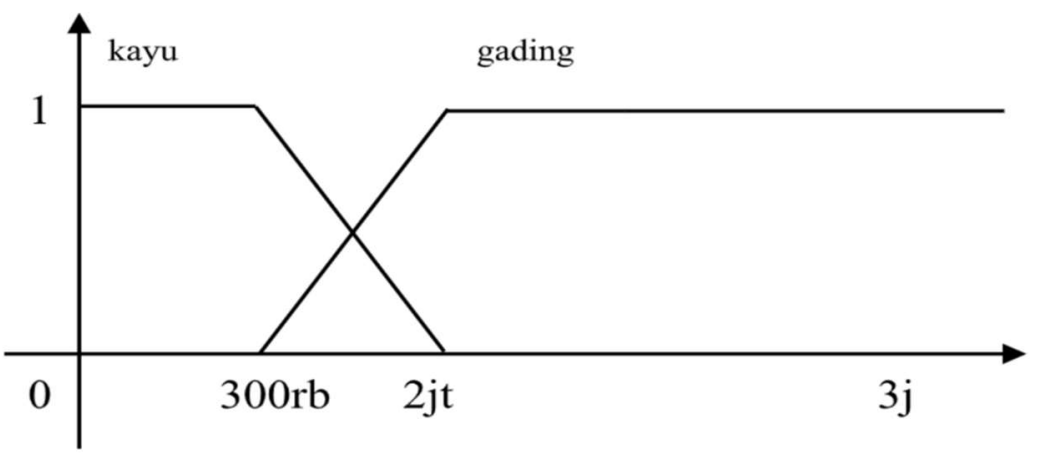

Gambar 2. Himpunan Handle 
c. Himpunan Pelet

Himpunan pelet digunakan untuk menentukan berapa jumlah pelet pada kayu. pelet merupakan gambar yang menempel pada kayu dikarenakan proses alam atau pembusukan atau penyakit pohon. Biasanya pelet berbentuk corak-corak, berwarna coklat sampai hitam. Tabel 3 menunjukkan tingkat fuzzy untuk pelet dan derajat keanggotaannya ditunjukkan pada Gambar 3.

Tabel 3. Pelet

\begin{tabular}{ccc}
\hline No & Pelet & Tingkat Fuzzy \\
\hline 1 & $1-4$ & Polos \\
\hline 2 & $2-8$ & Tidak Teratur \\
\hline 3 & $6-10$ & Motif \\
\hline
\end{tabular}

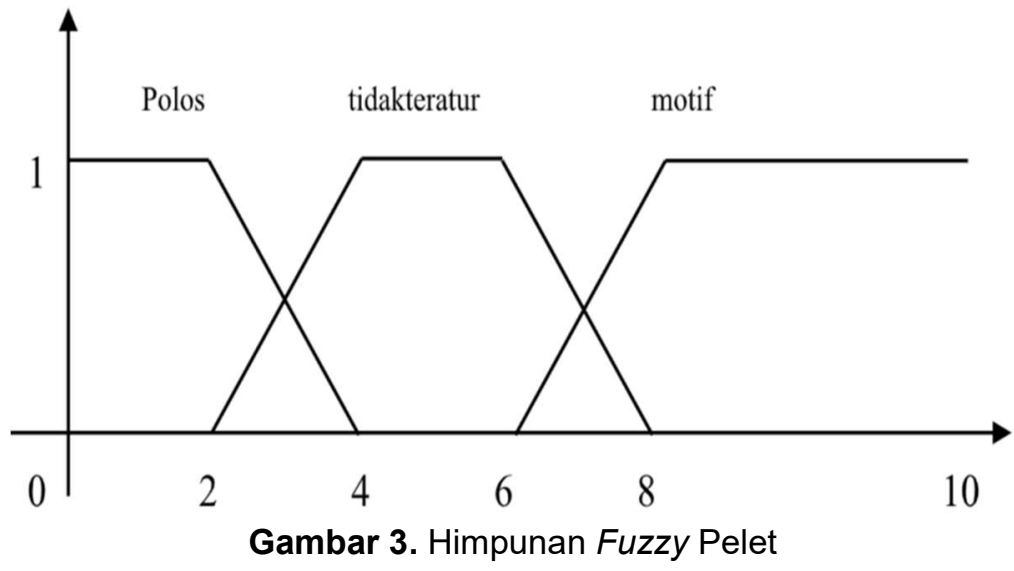

d. Himpunan Fuzzy Stok

Variabel stok memiliki 3 kategori yaitu Normal, Banyak, dan Langka seperti ditunjukkan pada Tabel 4. Fungsi keanggotaan pada himpunan fuzzy dapat diketahui pada Gambar 4.

Tabel 4. Stok

\begin{tabular}{ccc}
\hline No & Stok & Tingkat Fuzzy \\
\hline 1 & $1-15$ & Banyak \\
\hline 2 & $10-30$ & Normal \\
\hline 3 & $20-35$ & Langkah \\
\hline
\end{tabular}

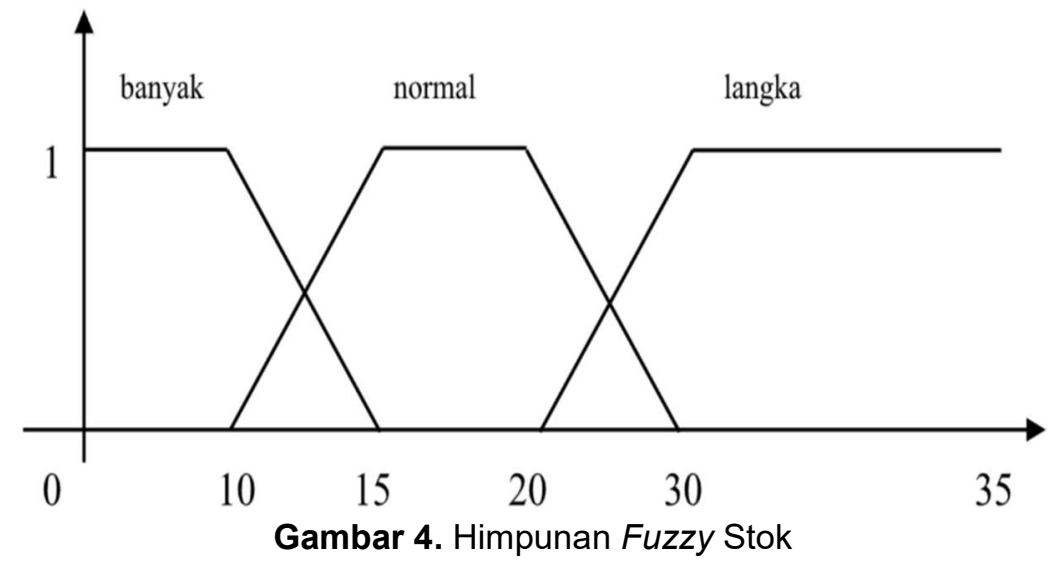

e. Himpunan Fuzzy Permintaan

Variabel Permintaan memiliki 3 kategori yaitu Sedikit, Normal, dan Banyak yang ditunjukkan pada Tabel 5. Gambar 5 menunjukkan fungsi keanggotaan pada himpunan fuzzy permintaan. 
Tabel 5. Permintaan

\begin{tabular}{ccc}
\hline No & Pelet & Tingkat Fuzzy \\
\hline 1 & $1-15$ & Sedikit \\
\hline 2 & $10-30$ & Normal \\
\hline 3 & $20-35$ & Banyak \\
\hline
\end{tabular}

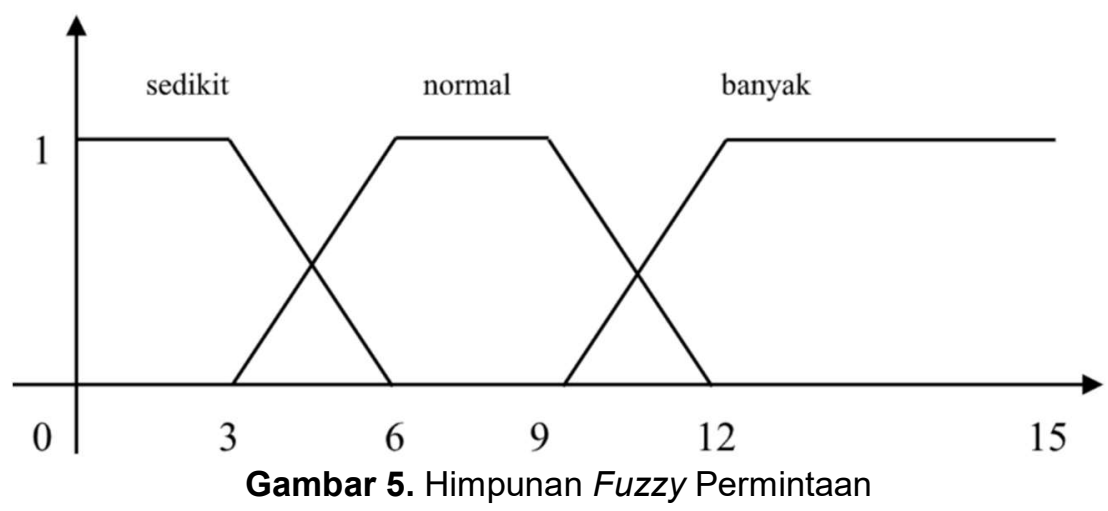

f. Himpunan Fuzzy Harga Jual

Himpunan Harga Jual merupakan hasil akhir dari sistem ini, yang nilainya ditunjukkan pada Tabel 6. Fungsi keanggotaan yang menyatakan harga jual warangka keris berdasarkan handle, pelet, stok, dan permintaan diperlihatkan pada Gambar 6.

Tabel 6. Harga Jual

\begin{tabular}{ccc}
\hline No & Pelet & Tingkat Fuzzy \\
\hline 1 & $100.000-1.000 .000$ & Murah \\
\hline 2 & $500.000-2.500 .000$ & Standar \\
\hline 3 & $2.000 .000-3.000 .000$ & Mahal \\
\hline
\end{tabular}

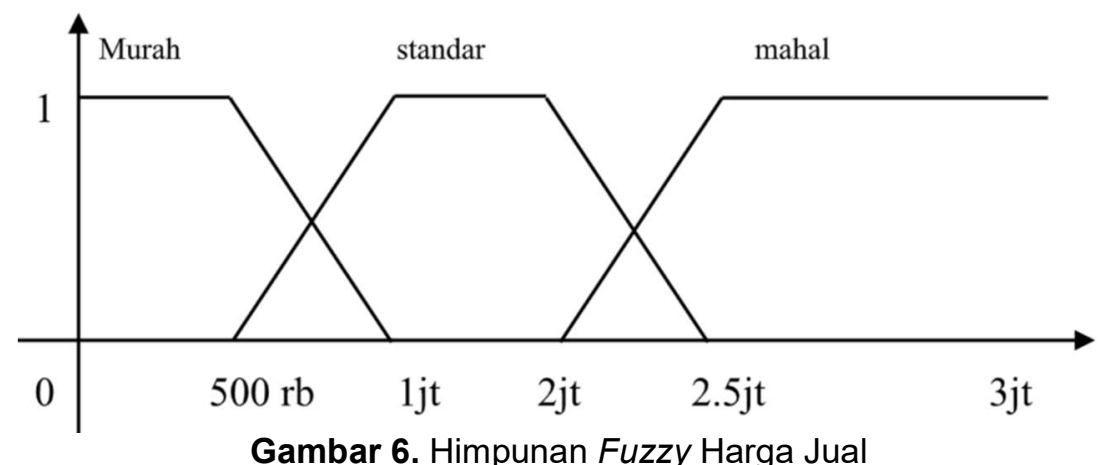

\subsection{Komposisi Aturan}

Dari aturan predikat yang ada, dapat dihasilkan komposisi aturan baru pada Tabel 7 dan Tabel 8 sebagai berikut :

Tabel 7. Rule Kualitas Kayu

\begin{tabular}{llll}
\hline \multirow{2}{*}{ No } & IF & & \multirow{2}{*}{ THEN } \\
\cline { 2 - 4 } & Handle & Pelet & \\
\hline 1 & Kayu & Polos & Rendah \\
\hline 2 & Kayu & Tidak Teratur & Standar \\
\hline 3 & Kayu & Motif & Tinggi \\
\hline 4 & Gading & Polos & Rendah \\
\hline 5 & Gading & Tidak Teratur & Standar \\
\hline 6 & Gading & Motif & Tinggi \\
\hline
\end{tabular}


Tabel 8. Rule Harga Jual Warangka

\begin{tabular}{|c|c|c|c|c|}
\hline \multirow[t]{2}{*}{ No } & \multicolumn{3}{|l|}{ IF } & \multirow[t]{2}{*}{ THEN } \\
\hline & Kualitas & Stok & Permintaan & \\
\hline 1 & Rendah & Banyak & Sedikit & Murah \\
\hline 2 & Rendah & Banyak & Normal & Murah \\
\hline 3 & Rendah & Banyak & Banyak & Standar \\
\hline 4 & Rendah & Normal & Sedikit & Murah \\
\hline 5 & Rendah & Normal & Normal & Standar \\
\hline 6 & Rendah & Normal & Banyak & Standar \\
\hline 7 & Rendah & Langkah & Sedikit & Standar \\
\hline 8 & Rendah & Langkah & Normal & Standar \\
\hline 9 & Rendah & Langkah & Banyak & Standar \\
\hline 10 & Standar & Banyak & Sedikit & Murah \\
\hline 11 & Standar & Banyak & Normal & Standar \\
\hline 12 & Standar & Banyak & Banyak & Tinggi \\
\hline 13 & Standar & Normal & Sedikit & Murah \\
\hline 14 & Standar & Normal & Normal & Standar \\
\hline 15 & Standar & Normal & Banyak & Tinggi \\
\hline 16 & Standar & Langkah & Sedikit & Murah \\
\hline 17 & Standar & Langkah & Normal & Standar \\
\hline 18 & Standar & Langkah & Banyak & Tinggi \\
\hline 19 & Tinggi & Banyak & Sedikit & Murah \\
\hline 20 & Tinggi & Banyak & Normal & Tinggi \\
\hline 21 & Tinggi & Banyak & Banyak & Tinggi \\
\hline 22 & Tinggi & Normal & Sedikit & Standar \\
\hline 23 & Tinggi & Normal & Normal & Standar \\
\hline 24 & Tinggi & Normal & Banyak & Tinggi \\
\hline 25 & Tinggi & Langkah & Sedikit & Standar \\
\hline 26 & Tinggi & Langkah & Normal & Tinggi \\
\hline 27 & Tinggi & Langkah & Banyak & Tinggi \\
\hline
\end{tabular}

\subsection{Defuzzyfikasi}

Defuzzifikasi rekomendasi penentuan harga jual untuk warangka keris menggunakan Logika Fuzzy Mamdani yaitu :

$$
y=\sum \frac{\mu(y) y}{\mu(y)}
$$

Dimana y adalah nilai crisp dan $\mu(\mathrm{y})$ adalah derajat keanggotaan y.

\section{Hasil dan Pembahasan}

Skenario uji coba adalah menerapkan fuzzy pada program kemudian dibandingkan antara hasil rekomendasi dari fuzzy dengan data yang sebenarnya, kemudian dihitung tingkat errornya. Uji coba akan dilakukan pada 20 sampel. Perhitungan berikut adalah contoh cara kerja fuzzy dalam melakukan rekomendasi. Setelah aturan dibentuk, maka dilakukan aplikasi fungsi implikasi. Sebagai contoh terdapat sebuah kasus sebagai berikut, penentuan harga warangka keris jika:

Handle

Pelet

$: 1.000 .000$

Stok

Permintaan 
Aturan yang berlaku adalah sebagai berikut, karena operator dari rule adalah AND maka nilai $\alpha$ -predikat dipilih yang minimum. Kemudian dengan menggunakan rumus (1) dan (2) dapat dihitung nilai tegas dari masing-masing variable :

[R1] IF handle Kayu AND pelet Tidak teratur THEN kualitas Standar

$$
\begin{aligned}
\alpha \text {-predikat1 } & =\mu \text { Kayu } \cap \mu \text { Tidak teratur } \\
& =\quad \min (\mu \text { Kayu[1.000.000], } \mu \text { Tidak teratur[7] }) \\
& =\min (0,58,0,5) \\
& =0,5
\end{aligned}
$$

Himpunan Rendah pada grafik keanggotaan variabel kualitas yaitu

$(x-20) / 20=0.5, x=30$

[R11] IF kualitas Standar AND stok Banyak AND permintaan Normal THEN harga Standar $\alpha$-predikat1 $=\mu$ Standar $\cap \mu$ Banyak $\cap \mu$ Normal

$$
\begin{array}{ll}
= & \min (\mu \operatorname{Rendah}[30], \mu \text { Sedikit[12], } \mu \text { Sedikit[10] }) \\
= & \min (0.5,0.6,0.67) \\
= & 0.5
\end{array}
$$

Himpunan Murah pada grafik keanggotaan variabel harga jual yaitu $(x-500.000) / 500.000=0.5, x=750.000$

[R14] IF kualitas Standar AND stok Normal AND permintaan Normal THEN harga Standar $\alpha$-predikat2 $=\mu$ standar $\cap$ Normal $\cap$ Normal

$$
\begin{array}{ll}
= & \min (\mu \text { Rendah }[30], \mu \text { Normal[12], } \mu \text { Normal[10] }) \\
= & \min (0.5,0.4,0.67) \\
= & 0.4
\end{array}
$$

Himpunan Murah pada grafik keanggotaan variabel harga jual yaitu $(x-500.000) / 500.000=0.4, x=700.000$

[R17] IF kualitas Standar AND stok Langka AND permintaan Normal THEN harga Standar $\alpha$-predikat2 $=\mu$ Standar $\cap$ Langka $\cap$ Normal

$$
\begin{aligned}
& =\quad \min (\mu \operatorname{Standar}[30], \mu \text { Langka[0], } \mu \text { Normal[12] }) \\
& =\quad \min (0.5,0,0.67) \\
& =0
\end{aligned}
$$

Himpunan Murah pada grafik keanggotaan variabel harga jual yaitu $(x-500.000) / 500.000=, x=500.000$

Defuzzifikasi rekomendasi penentuan harga jual untuk warangka keris menggunakan Logika Fuzzy Mamdani yaitu :

$$
\begin{aligned}
& y=\sum \frac{\mu(y) y}{\mu(y)} \\
& \mathrm{y}=\frac{0.5 * 750.000+0.4 * 700.000+0 * 500.000}{0.5+0.4+0} \\
& \mathrm{y}=\frac{375.000+2 \quad .000}{0,9}=\frac{655.000}{0.9}=727.778
\end{aligned}
$$


Proses-proses fuzzyfikasi yang sudah dilakukan diatas dengan memberikan sampel yang harus dihitung sehingga didapatkan harga jual warangka keris, setelah dilakukan penerapan logika fuzzy akhirnya didapatkan harga jual warangka keris sebagai senilai Rp 727.778.

Setelah tahap implementasi selesai, maka dilanjutkan dengan pengujian dari implementasi yang telah dibuat. Pengujian sistem dilakukan dengan tujuan untuk menjamin sistem yang dibangun sesuai dengan hasil analisa dan perancangan sehingga dapat dibuat satu kesimpulan akhir. Pengujian dilakukan dengan melihat MAE(Mean Absolute Error) dengan dataset sebanyak 20 buah yang ditunjukkan pada Tabel 9 berikut. Tabel 9 menunjukkan perbandingan harga sebenarnya dan harga yang direkomendasikan oleh sistem fuzzy.

Tabel 9. Perbandingan harga sebenarnya dan harga prediksi

\begin{tabular}{ccc}
\hline No & Harga Sebenarnya & Harga Prediksi dari Fuzzy \\
\hline 1 & 790.000 & 727.979 \\
\hline 2 & 350.000 & 300.000 \\
\hline 3 & 1.000 .000 & 900.000 \\
\hline 4 & 970.000 & 935.000 \\
\hline 5 & 890.000 & 941.176 \\
\hline 6 & 963.000 & 911.765 \\
\hline 7 & 882.353 & 850.000 \\
\hline 8 & 800.000 & 794.118 \\
\hline 9 & 788.000 & 750.000 \\
\hline 10 & 2.730 .000 & 2.683 .333 \\
\hline 11 & 723.000 & 707.143 \\
\hline 12 & 2.500 .000 & 2.621 .429 \\
\hline 13 & 700.000 & 695.455 \\
\hline 14 & 800.000 & 730.000 \\
\hline 15 & 850.000 & 815.350 \\
\hline 16 & 821.000 & 843.918 \\
\hline 17 & 2.800 .000 & 2.780 .000 \\
\hline 18 & 750.000 & 750.000 \\
\hline 19 & 650.000 & 407.059 \\
\hline 20 & 550.000 & 533.333 \\
\hline
\end{tabular}

MAE dapat didefinisikan sebagai berikut :

$M A E=\frac{1}{n} \sum_{i=1}^{n}|f i-y i|$

Keterangan :

Dimana $f i$ adalah nilai hasil prediksi, yi adalah nilai sebenarnya dan $n$ adalah jumlah data. Berdasarkan formula 1 di atas MAE secara intuitif menghitung rata -rata error dengan memberikan bobot yang sama untuk seluruh data $(\mathrm{i}=1 \ldots \mathrm{n})$.

Berdasarkan pengertian di atas maka perhitungan MAE pada sistem ini adalah sebagai berikut :

$$
\begin{aligned}
M A E=(\mid 790.000 & -727.979|+| 350.000-300.000|+| 1.000 .000-900.000 \mid \\
& +|970.000-935.000|+|890.000-941.176|+|963.000-911.765| \\
& +|882.353-850.000|+|800.000-794.118|+|788.000-750.000| \\
& +|2.730 .000-2.683 .333|+|723.000-707.143|+|2.621 .429-2.500 .000| \\
& +|700.000-695.455|+|800.000-730.000|+|850.000-815.350| \\
& +|843.918-821.000|+|2.800 .000-2.780 .000|+|750.000-750.000| \\
& +|650.000-407.059|+|550.000-533.333|) / 20 \\
M A E=\frac{865.041}{20} & =43.252,05
\end{aligned}
$$


Hasil perhitungan error menggunakan Teknik Peramalan MAE (Mean Absolute Error) dan hasil nilai error yang di dapat dengan MAE adalah Rp 43.252,05. Sehingga sistem ini mempunyai selisih error sebesar Rp. 43.252,05.

\section{Kesimpulan}

Berdasarkan hasil pembahasan yang sudah dilakukan sebelumnya, penelitian ini mengambil kesimpulan sebagai berikut :

1. Kesimpulan dari penelitian ini adalah penentuan harga jual warangka keris dengan menerapkan logika fuzzy mamdani cukup akurat untuk memprediksi harga warangka keris dengan rata-rata selisih error adalah Rp 43.252,05.

2. Dengan adanya sistem ini para penjual dan pengrajin yang baru saja berkecimbung dalam dunia bisnis warangka keris dapat menggunakan sistem ini untuk membantu menemukan harga warangka keris, karena harga yang dihasilkan sudah bisa dikatakan harga standar.

Setelah menyelesaikan penelitian ini, ada beberapa kekurangan untuk ada beberapa kekurangan yang perlu diperbaiki untuk penelitian selanjutnya:

1. Dalam penelitian ini tidak menyertakan jenis kayu dan jenis pelet pada warangka keris.

2. Dalam penelitian ini tidak menyertakan harga pamor keris itu dikarenakan pamor tidak terbuat dari bahan baku kayu melainkan terbuat dari bahan baku seperti titanium, besi baja , karbon , chlor, nikel, emas maupun campuran dari keduanya.

Untuk penelitian selanjutnya dapat menambahkan jaringan syaraf tiruan untuk dapat mempelajari data secara otomatis untuk input dari fuzzy yang ada.

\section{Referensi}

[1] A. Widiyantoro et al., "Menerapkan Logika Fuzzy Mandani Untuk Menentukan Harga Jual Batik," Techno.COM, vol. 13, no. 2, pp. 69-74, 2014.

[2] S. S. Himawan, Asep Saefullah, "Analisa dan Perancangan Sistem Informasi Penjualan Online ( E- Commerce ) pada CV Selaras Batik Menggunakan Analisis Deskriptif," Sci. J. Informatics, vol. 1, no. 1, pp. 53-64, 2014.

[3] A. D. Zulhida and R. Haryanto, "Spesialisasi Kegiatan Produksi dan Kemitraan Subkontrak pada Klaster Batik Kota Pekalongan," Wil. dan lingkuangan, vol. 4, pp. 95-110, 2016.

[4] E. Setiawati, F. Ekonomi, and U. M. Surakarta, "Pengembangan Komoditas Batik: Determinasi Budaya Ekonomi Dan Perubahan Struktur Kebijakan Terhadap Perkembangan Usaha Ekonomi Lokal ( Studi Tentang Pengusaha Batik Laweyan Surakarta )," Ekon. dan Bisnis, vol. XVIII, no. 1, pp. 119-134, 2015.

[5] M. Ihsan Zul, dan Satria Perdana Arifin, and K. kunci, "Sistem Pendukung Keputusan untuk Pembelian Smartphone Menggunakan Metode Simple Additive Weight dan Fuzzy Associative Memory," J. KomputerTerapan, 2016.

[6] A. Bahroini, A. Farmadi, and R. A. Nugroho, "Prediksi Permintaan Produk Mie Instan Dengan Metode Fuzzy Takagi-Sugeno," IImu Komput., vol. 3, no. 2, pp. 220-230, 2016.

[7] T. S. (teguhsusyanto@gmail. com. Tri Handayani, Wawan Laksito, "Sistem pendukung keputusan beasiswa diklat dengan fuzzy madm," TIKomSiN, vol. 1 no 2, pp. 29-34, 2013.

[8] A. Lubis, "Sistem Informasi Pendukung Keputusan Terhadap Mutu Lulusan dengan Metode Fuzzy Model Tsukamoto," Sist. Inf. Bisnis, vol. 2, pp. 87-95, 2014.

[9] S. Ms. Suyanto, Artificial Intelligence, Edisi Revisi. 2011.

[10] H. Kusumadewi, Sri; Purnomo, Aplikasi Logika Fuzzy Pendukung Keputusan, 2nd ed. 2010. 